EPJ Web of Conferences 82, 01039 (2015)

DOI: $10.1051 /$ epjconf/20158201039

(C) Owned by the authors, published by EDP Sciences, 2015

\title{
Computer simulation of the fire-tube boiler hydrodynamics
}

\author{
Sergei A. Khaustov ${ }^{a}$, Alexander S. Zavorin, Konstantin V. Buvakov and Vyacheslav A. Sheikin \\ National Research Tomsk Polytechnic University, 634050 Tomsk, Russia
}

\begin{abstract}
Finite element method was used for simulating the hydrodynamics of firetube boiler with the ANSYS Fluent 12.1.4 engineering simulation software. Hydrodynamic structure and volumetric temperature distribution were calculated. The results are presented in graphical form. Complete geometric model of the fire-tube boiler based on boiler drawings was considered. Obtained results are suitable for qualitative analysis of hydrodynamics and singularities identification in fire-tube boiler water shell.
\end{abstract}

\section{Introduction}

Fire-tube boilers currently have a high priority on the market of heating equipment. Features of such boilers allow it to be used in decentralized heating systems, providing consumers with heat, regardless of housing and utility companies or industrial enterprises. This equipment shows high efficiency, reliable performance and good thermal and technical indicators. These and some other features led to the overall use of fire-tube boilers in heating systems throughout Russia [1].

The design of fire-tube boiler has many advantages over water-tube boilers of the type [1]: the performance coefficient of the fire-tube boilers reaches 95\%, and there are some additional advantages - best maintainability, full automation and low price in comparison to water-tube analogues. But on the other hand the fact that the fire-tube boiler usually has a water shell draws attention to questions connected with optimal coolant temperature distribution along its volume, because fire-tube boilers have a high probability of large-scale deposit formation. Limescale deposits caused by irregular local thermal loads can decrease reliability of fire-tube boiler. The wall thermal stresses in boiler are mostly determined by the condition of the inner surface (on the side of the coolant); therefore hydrodynamics of fire-tube boilers requires much attention from both the designers and maintenance services.

Importance of fire-tube boiler water treatment is also caused by some design features: primarily by the high density of heat fluxes through the fire-tube surfaces. In modern fire-tube boilers value of this parameter is about three times higher than the water-tube boilers heat fluxes. High rates of heat flux density through the heating surfaces cause significant thermal loads. In such circumstances, the absence of intensive water cooling can cause metal overheating and lead to a crash: wall bumping and deformation, rupture of the welds [2].

\footnotetext{
${ }^{a}$ Corresponding author: khaustovsa@tpu.ru
}

This is an Open Access article distributed under the terms of the Creative Commons Attribution License 4.0, which permits unrestricted use, distribution, and reproduction in any medium, provided the original work is properly cited. 


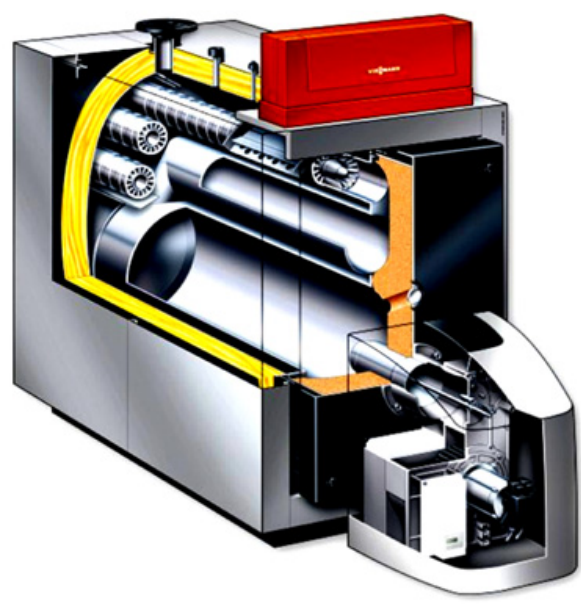

(a)

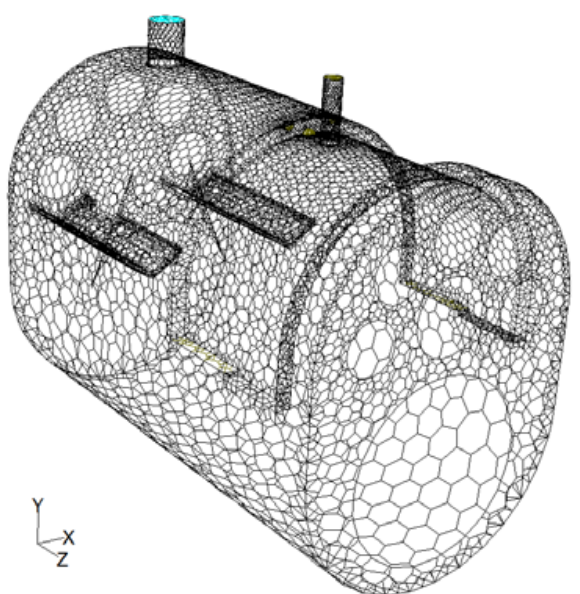

(b)

Figure 1. Boiler Vitoplex 300 [3] (a) and computational polyhedral mesh of its water volume (b).

Full-scale multiple-factor experimental research of three-dimensional dynamics of turbulent flows in the branch pipes of the boiler, as well as free convection directly in the water volume is quite laborconsuming. Therefore, nowadays computational simulation with the use of widely approved engineering software is widely used to solve listed boiler hydrodynamics problems.

\section{Object of study}

In order to study the hydrodynamics of the fire-tube boiler water shell, to identify its features and estimate a number of its characteristic parameters a series of numerical experiments using ANSYS Fluent engineering software was made. For the computational research, a full geometrical model of 3D-model of water volume boiler Viessmann Vitoplex 300 (Fig. 1) was implemented. A computational mesh was designed by means of the ANSYS Workbench based on the original drawings.

The computational mesh (Fig. 1) consists of 45387 polyhedral cells, 252006 polygonal interior faces and 217156 nodes. Total volume intended for water in boiler: $0.215 \mathrm{~m}^{3} .2580$ polygonal wall faces are used for $1.76 \mathrm{~m}^{2}$ of paired fire-tube furnace walls: first $\left(1.32 \mathrm{~m}^{2}\right)$ and second processes of flue gases $\left(0.44 \mathrm{~m}^{2}\right) .7954$ polygonal wall faces are used for $1.72 \mathrm{~m}^{2}$ of third flue gases process walls. 9482 polygonal wall faces are used $3.23 \mathrm{~m}^{2}$ of outer walls covered by insulation, providing a heat loss to environment $0.5 \%$ at most. 45 polygonal outlet faces and 285 polygonal inlet faces are used for mass flow of liquid water equal to $1.09 \mathrm{~kg} / \mathrm{s}$.

The initial data for calculation included: inlet medium - liquid water $\left(100 \% \mathrm{H}_{2} \mathrm{O}\right)$; its temperature $70{ }^{\circ} \mathrm{C}$; output water temperature should be $95{ }^{\circ} \mathrm{C}$ [3]. Heat flow is set as the boundary conditions for the heating surfaces. Uneven heat flow for paired fire-tube furnace walls (first and second processes of flue gases) was calculated by computer simulation (Fig. 2) using ANSYS FLUENT and a set of models given in $[4,5]$. Heat flow through the walls of the third process pipes is calculated according to the equations of heat transfer $[2,6]$ and its value is $18850 \mathrm{~W} / \mathrm{m}^{2}$.

\section{Calculation results}

Results of computer simulation show that a coolant specific volume value of $1.83 \mathrm{~m}^{3} / \mathrm{kW}$ causes low rates of average flow velocity magnitude and leads to an irregular hydrodynamic circulation (Fig. 3) 

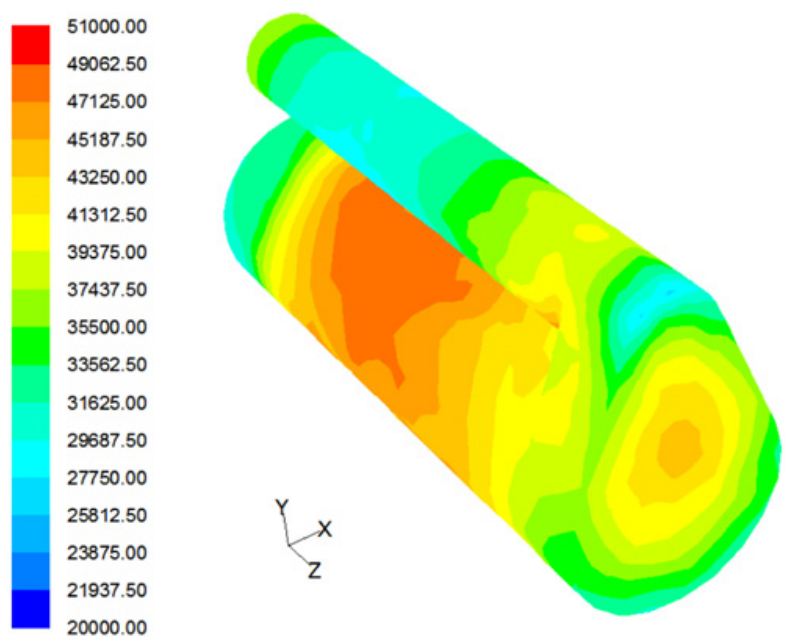

Figure 2. Fire-tube furnace wall heat fluxes $\left(\mathrm{W} / \mathrm{m}^{2}\right)$.

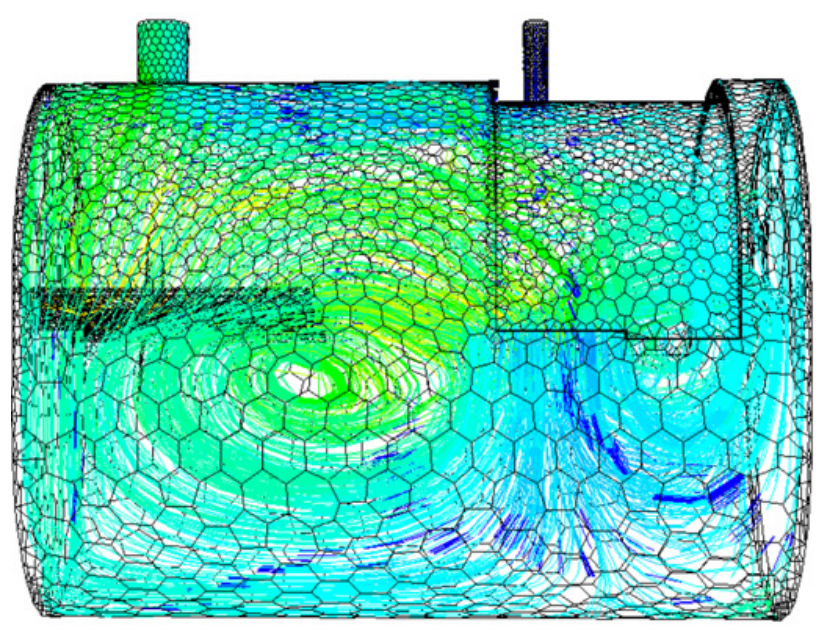

Figure 3. Hydrodynamic structure of boiler water volume (pathlines).

with natural convection at speeds less than $0.1 \mathrm{~m} / \mathrm{s}$. For this reason, the maximum value for the thermal stresses in the flue-heating surfaces in terms of preventing boiling in the wall areas is much lower than in water-tube boilers. Thus, the value of thermal stress of the flame tube should be considered as the main factor determining the reliable and efficient operation of the test boiler.

In addition a huge coolant flow rate with low flow velocity magnitudes results in intense precipitation of suspended particles of sludge at the bottom of the boiler water shell and horizontal heating surfaces. These areas are further exposed to intense limescale corrosion.

In the boiler water volume there is a kind of organized vortex structure (Fig. 3). The coolant is supplied by a special channel on a tangent to this vortex at the level of the furnace. Next water sinks to the bottom of the water volume, which is in contact with the most intense heat flow from the combustion chamber (Fig. 2). Heated, the upward flow of coolant is shifted to the boiler rear part, where steel flow splitters are installed. Internal flow of heated water flows close to the furnace and then directed to the 


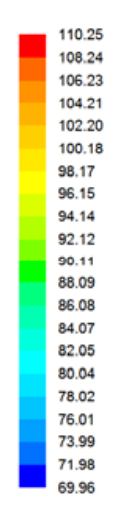

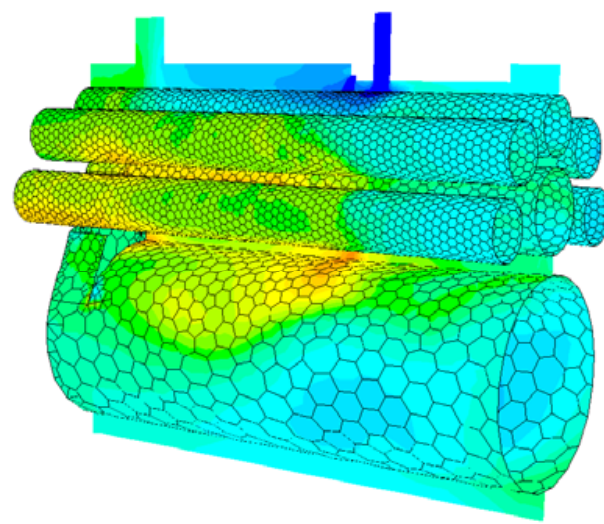

(a)

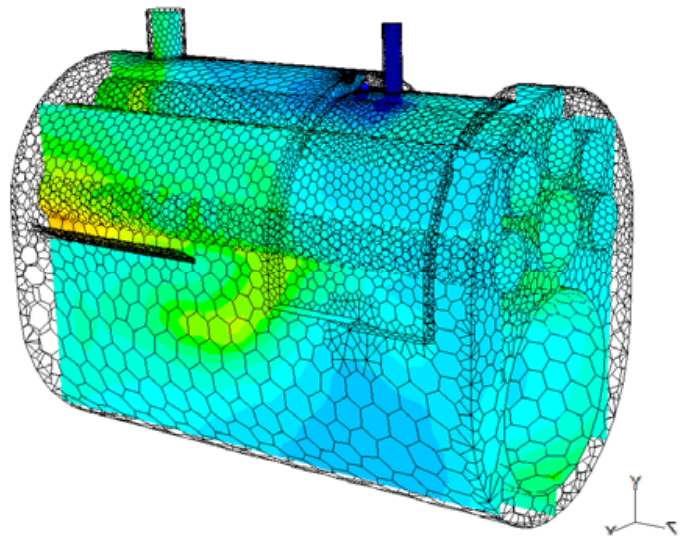

(b)

Figure 4. Contours with color indexation according to the temperature $\left({ }^{\circ} \mathrm{C}\right)$ in hydraulic section of the boiler Vitoplex 300: (a) in the wall region; (b) in the water volume.

second and third gas process area where it heats up to the desired temperature and leaves the boiler. The external flow has a lower temperature, because it occurs at a greater distance from the furnace heating surface. The splitter sends it to the next round on the vortex, where it is mixed with a new portion of the coolant.

\section{Limescale formation prevention}

According to the results of boiler hydrodynamics computer simulation the maximum value of the flowing water local temperature is $110^{\circ} \mathrm{C}$ (Fig. 4). In areas covered by sludge, temperature of metal and coolant will be far above designated value of $110^{\circ} \mathrm{C}$, resulting in a local overheating of the pipe walls, boiling and intensification of the processes of scaling. Coolant boiling, in its turn, not only doesn't wash away the sludge, but also exacerbates its negative impact on the metal of heating surfaces and intensifies local deposition of slurry seals. Therefore fire-tube boiler requires fine water treatment for preventing limescale formation.

In this connection, the pressure in the water volume in order to avoid boiling should be chosen not lower the level of 4 bar, which corresponds to saturation temperature $t_{\mathrm{s}} \gg 110{ }^{\circ} \mathrm{C}$.

\section{Conclusion}

Thus, using the software package ANSYS a detailed picture of the Viessmann Vitoplex 300 boiler water shell, suitable for qualitative analysis of its hydrodynamics and singularities identification, is obtained. In particular it is shown that the heating surfaces thermal stress values is a major factor of fire-tube boiler reliability. All loads must be maintained with the calculated hydraulic pressure mode and coolant mass flow to avoid boiling and reduce the possibility of corrosion and scaling. Operation of the boiler with an inappropriate or broken water treatment system should not be allowed, as well as a number of violations of operating modes: such as disabling circulation pumps, changing the order of connection for the coolant; continuous operation without blowdown.

For further development required to investigate a dependence of construction and mode characteristics of the boiler on boiler hydrodynamics and its thermal parameters. 
The reported study was partially supported by the Ministry of education and science of The Russian Federation, state order No. 13.948.2014/K.

\section{References}

[1] S.A. Khaustov, A.S. Zavorin, Siberian Journal of Science 12, 21 (2014)

[2] Ju.M. Lipov, Ju.F. Samojlov, T.V. Vilenskij, Komponovka i teplovoj raschet parovogo kotla (Jenergoatomizdat, Moscow, 1988) [In Russian]

[3] "Vitoplex 300 - Viessmann," http://www.viessmann.ru/ru/Industrie-Gewerbe/ produkte/Medium_boilers_oil_html/Vitoplex-300.html, Oct. 24, 2014

[4] A.S. Zavorin, S.A. Khaustov, N.A. Zaharushkin, IOP Conf. Series: Materials Science and Engineering 66, 012029 (2014)

[5] S.A. Khaustov, A.S. Zavorin, R.N. Fisenko, Bulletin of Tomsk Polytechnic University 322, 43 (2013)

[6] Teplovoy raschet kotlov (Normativny metod). (Saint-Petersburg: SPO CKTI 1998) [In Russian] 